\begin{tabular}{c|c|c}
\hline \hline & MARINE ECOLOGY PROGRESS SERIES \\
Mol. 225: 45-52, 2002 & Mar Ecol Prog Ser & Published January 11 \\
\hline \hline
\end{tabular}

\title{
Mega-epibenthic diversity: a polar comparison
}

\author{
Andreas Starmans, Julian Gutt* \\ Alfred-Wegener-Institut für Polar- und Meeresforschung, PO Box 120161, 27568 Bremerhaven, Germany
}

\begin{abstract}
The diversity of Arctic (off northeast Greenland) and Antarctic (Weddell and Bellingshausen Seas) megabenthic assemblages was compared using underwater video at depths between 30 and $550 \mathrm{~m}$. The number of taxa found at each station was highest on the Weddell Sea shelf, which can be interpreted as being a result of the long isolation of the Antarctic fauna. However, the withinhabitat $(\alpha)$ diversity of the Weddell Sea assemblages did not differ significantly from those off Greenland or in the Bellingshausen Sea in a comparable depth range. This is apparently due to the similarity in dominance patterns, independent of species numbers. The Bellingshausen Sea and Greenland Sea stations exhibited similar between-habitat $(\beta)$ diversity patterns, while the Weddell Sea stations showed a slightly higher $\beta$-diversity and a pronounced higher overall diversity. This can be partly explained by the development of an epibiotic behaviour by several Antarctic suspension-feeding species. On the shallow shelf off Northeast Greenland the $\alpha$-diversity was low, but the $\beta$-diversity was relatively high compared to the other areas sampled. This may be due to the relatively high impact of physical and biological disturbances at shallower depths and the more stable environmental conditions in the deeper parts of all 3 investigation areas.
\end{abstract}

KEY WORDS: Mega-epibenthos · Antarctic · Arctic $\cdot$ Biodiversity $\cdot$ Between-habitat diversity Resale or republication not permitted without written consent of the publisher

\section{INTRODUCTION}

Similarities and dissimilarities between Arctic and Antarctic benthos have long been discussed in the literature (Dunbar 1968, 1977, Hedgpeth 1971, George 1977, Knox \& Lowry 1977, Dayton 1990, Dayton et al. 1994). Despite some obvious environmental similarities such as polar position, low water temperatures, strong seasonality in light regime, ice cover and primary production, the benthos of Arctic and Antarctic waters differs considerably in certain ecological respects, including higher species richness and diversity in the Antarctic (George 1977, Knox \& Lowry 1977, White 1984, Dayton 1990). These notable dissimilarities have generally been ascribed to factors such as major differences in geological history, recent interchange with adjacent oceans, degree of zoogeographic isolation, impact from land and freshwater, as well as the age and variability of sea ice (Hempel 1985, Dayton et al. 1994).

*Corresponding author. E-mail: jgutt@awi-bremerhaven.de
The conclusions reached in literature reviews may be undue overgeneralisations, since most of them are based on what might be biased data because of differences in the spatial scale and methodology of the investigations (Gutt 1991, Arntz et al. 1997). The use of a 'remotely operated vehicle' (ROV) has made it possible to carry out a methodologically identical comparison between Arctic and Antarctic bottom communities.

The study sites, both in the Arctic and Antarctic, belong to the permanent pack-ice zone (Hempel 1985), but coastal polynyas of varying size do occur during the summer (Yevsyeyev 1990, Lukin \& Provorkin 1992, Schneider \& Budéus 1994). The Arctic area selected for investigation comprised the shelf off northeast Greenland in the Greenland Sea, which consists of a system of shallow banks $(<100 \mathrm{~m})$ separated by troughs with a depth $>400 \mathrm{~m}$. Fine-grained sediments cover the bottom and sloping sides of the troughs, whereas coarser fractions predominate on the shallower banks. Here, a pronounced depth zonation is a conspicuous feature of the megabenthic distribution (Piepenburg \& Schmid 1996). 
The Antarctic area investigated included the deep $(<500 \mathrm{~m})$, narrow shelf of the eastern Weddell Sea in the Atlantic Sector of the Southern Ocean, and the shelf of the Bellingshausen Sea in the Pacific Sector. Poorly sorted sediments were mainly found in these areas (Starmans et al. 1999). In contrast to the Bellingshausen Sea, the benthos of the Weddell Sea is already relatively well known. Voß (1988) distinguished 2 major macrobenthic assemblages on the shelf of the eastern Weddell Sea, referred to as 'Eastern' and 'Southern', which were confirmed by Galéron et al. (1992), Piepenburg et al. (1997), Gutt \& Starmans (1998) and Starmans et al. (1999).

Since analysis of between-habitat diversity was of particular interest, a comparison of shelf areas of similar size and at a comparable depth was required, independent of community structure. The aims of this study were to compare diversity patterns at different scales: (1) in single samples, within-habitat $(\alpha)$ diversity; (2) between stations within the same area of investigation, between-habitat ( $\beta$ ) diversity; (3) between Arctic and Antarctic megabenthic assemblages, which can be considered as $\delta$-diversity, being defined as change in species composition between areas of $\gamma$ diversity (Magurran 1988).

\section{MATERIALS AND METHODS}

Field sampling. The investigations were carried out aboard the RV 'Polarstern' during the expeditions ANT VI/3 (Weddell Sea, Antarctica, 1988), ANT XI/3 (Bellingshausen Sea, Antarctica, 1994) and ARK IX/2-3 (Northeast Greenland, 1993) (Fig. 1): for cruise reports see Fütterer (1988), Hirche \& Kattner (1994) and Miller \& Grobe (1996). Data were collected using an ROV, (Sprint 103).

The Arctic stations were split into 2 groups: shallow (35 to $125 \mathrm{~m}$ ) and deep (180 to $375 \mathrm{~m})$. All Antarctic stations were situated on the continental shelf at a depth of between 140 and $585 \mathrm{~m}$. This resulted in 4 different sampling areas-Arctic: off Northeast Greenland, shallow (35 to $125 \mathrm{~m}$ ) and deep (180 to $375 \mathrm{~m})$; Antarctic: Weddell Sea, continental shelf (195 to $555 \mathrm{~m}$ ); Bellingshausen Sea, continental shelf (140 to $585 \mathrm{~m}$ ).

Ten stations covering a similar area were randomly chosen for each of the 4 sample areas. Most stations comprised between 60 and 90 min video observation of the sea floor. In order to achieve straight transects, the vehicle was left suspended and the ship allowed to drift. The transects had an average length of roughly $1 \mathrm{~km}$. The width of the transects (average approx. $50 \mathrm{~cm}$ ) was indicated by 2 parallel laser beams, which acted as a scale on the image. Comparable sample sizes were obtained by randomly selecting continuous video footage of $100 \mathrm{~m}^{2}$ of sea floor for analysis. The optical resolution of the cameras permitted all organisms larger than $1 \mathrm{~cm}$ to be counted. In addition to the videos, a minimum of 100 still photographs were taken by the ROV at each station, as an aid to identifying the taxa present.

Identification and counting. Experts assisted in the identification of the different species/taxa. With few exceptions all visible organisms were counted; however, small encrusting forms were not considered. Where possible colonies of certain colonial organisms, e.g. bryozoans and ascidians, were counted as single individuals; for other colonial taxa the percentage cover of the sea floor was multiplied by 2 to obtain a rough equivalent to the abundances of other taxa. In
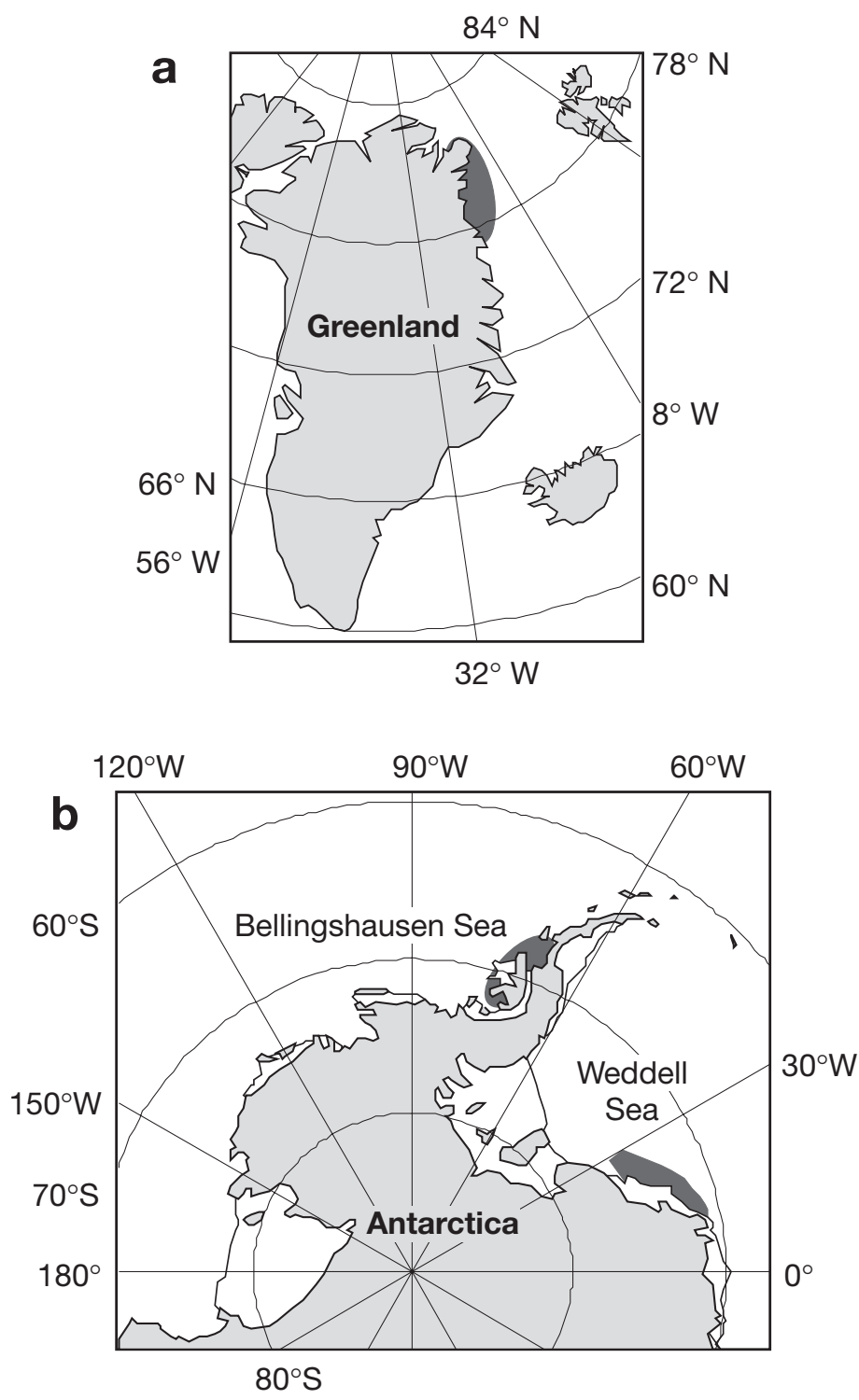

Fig. 1. Study areas: (a) off Northeast Greenland, (b) Antarctic 
subsequent calculations these values were treated as true abundances. Infaunal species were included when part of their body was visible.
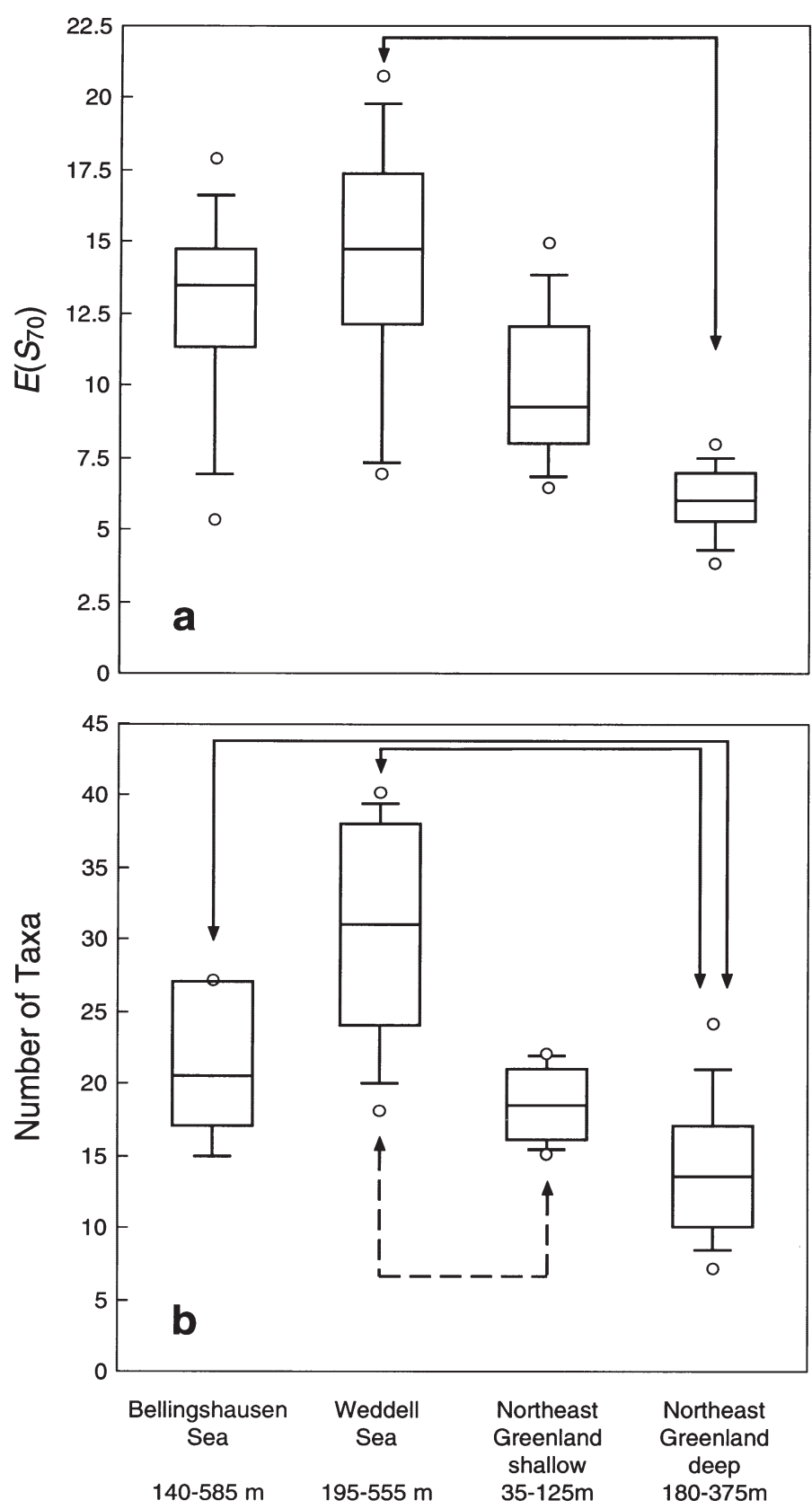

Fig. 2. Within-habitat diversity $(\alpha)$. (a) Rarefaction richness estimator $E\left(S_{70}\right)$; (b) number of taxa in megabenthic assemblages in Weddell and Bellingshausen Seas and off northeast Greenland. Box plots: the 5 horizontal lines represent 10th, 25th, 50th (median), 75th and 90th percentiles of the variable; circles represent outliers; arrows indicate significant differences (post-hoc multiple comparison after Nemenyi, $\mathrm{p}<0.05$ ) between all investigation areas (continuous arrows) and investigation areas at comparable depth $(>140 \mathrm{~m}$ ) (dotted arrows). Sample size $(n)=10$ for each study site
Data analysis. The diversity of single samples (within-habitat or $\alpha$-diversity) was compared using firstly the number of taxa recorded, and secondly the normalised expected number of taxa, calculated after Hurlbert's (1971) modification of Sanders (1968) rarefaction method. This method calculates the expected number of taxa, $E\left(S_{n}\right)$, in a reduced standardised sample of $n$ individuals selected from the given sample. For the rarefaction approach a reduced number of individuals $(\mathrm{n}=70$ ) was chosen which took into account the lowest abundances at each station.

In order to assess the between-habitat $(\beta)$ diversity, the Bray-Curtis similarities (Bray \& Curtis 1957) with double square-root-transformation were calculated for the 4 investigation areas (Magurran 1988). The higher the overall similarities are, the lower the $\beta$-diversity. Also an alternative approach was used for both number of taxa and $E\left(S_{70}\right)$ values which shows the pattern of diversity as single curves for each of the 4 areas. This was done by plotting the mean values of the following: (1) number of taxa and diversity, $E\left(S_{70}\right)$, of 1 out of a total of 10 stations selected 10 times at random with replacement ( $\alpha$-diversity, based on $100 \mathrm{~m}^{2}$, first data points); (2) cumulative number of taxa and diversity, $E\left(S_{70}\right)$, of 10 combinations of 2 to 9 stations randomly chosen (based on 200 to $900 \mathrm{~m}^{2}$, second to ninth data point); and (3) total number of taxa and diversity, $E\left(S_{70}\right)$, of all 10 stations from the different areas of investigation (representing $1000 \mathrm{~m}^{2}$, last data point). The steeper the slope for the resulting $E\left(S_{70}\right)$ graph, the higher the $\beta$-diversity. All calculations involved organisms which had been identified to the genus or species level.

Non-parametric Kruskal-Wallis tests and post-hoc multiple comparison (after Nemenyi, see Sachs 1984) were used to test the significance of differences $(p<0.05$, 2-tailed) between the 4 areas of investigation.

Data analysis was performed using the computer programmes PRIMER (Clarke \& Warwick 1994), BioDiversity Pro (The Natural History Museum, London, and Scottish Association for Marine Science, Oban) and StatView (Abacus Concepts, Inc.).

\section{RESULTS}

\section{Within-habitat $(\alpha)$ diversity}

The $E\left(S_{70}\right)$ diversity values varied markedly among the 4 investigation areas (Fig. 2a). The highest values were calculated for the Weddell Sea; however, the lowest values were similar for all areas. The post-hoc multiple comparison showed that only the diversity at the Weddell Sea stations was significantly higher than at the shallow stations off northeast Greenland. No sta- 
tistical differences were discernible between stations at a comparable depth (>140 m).

The number of taxa found at each station showed a similar pattern (Fig. 2b). The median value ranged from 31.0 in the Weddell Sea down to 20.5 in the Bellingshausen Sea in the Antarctic, whereas values off northeast Greenland varied between 18.5 and 13.5 for the deeper and shallower stations, respectively. Values for the Weddell and Bellingshausen Sea stations were significantly higher than the values for the shallower stations off northeast Greenland. However, comparing results from a similar depth (>140 m) alone showed that only the number of taxa at the Weddell Sea stations was significantly higher than at the stations off northeast Greenland.

\section{Between-habitat $(\beta)$ diversity}

There was a broad range in similarity coefficients within the investigation areas (Fig. 3). The shallow stations off northeast Greenland showed the widest range ( 7.7 to 69.8 ) and had the lowest median, indicating a high $\beta$-diversity. The similarities for these stations differed significantly from those of the deeper Arctic and the Bellingshausen Sea, although not from the Weddell Sea stations. Comparison of stations below $140 \mathrm{~m}$ showed no statistical differences.

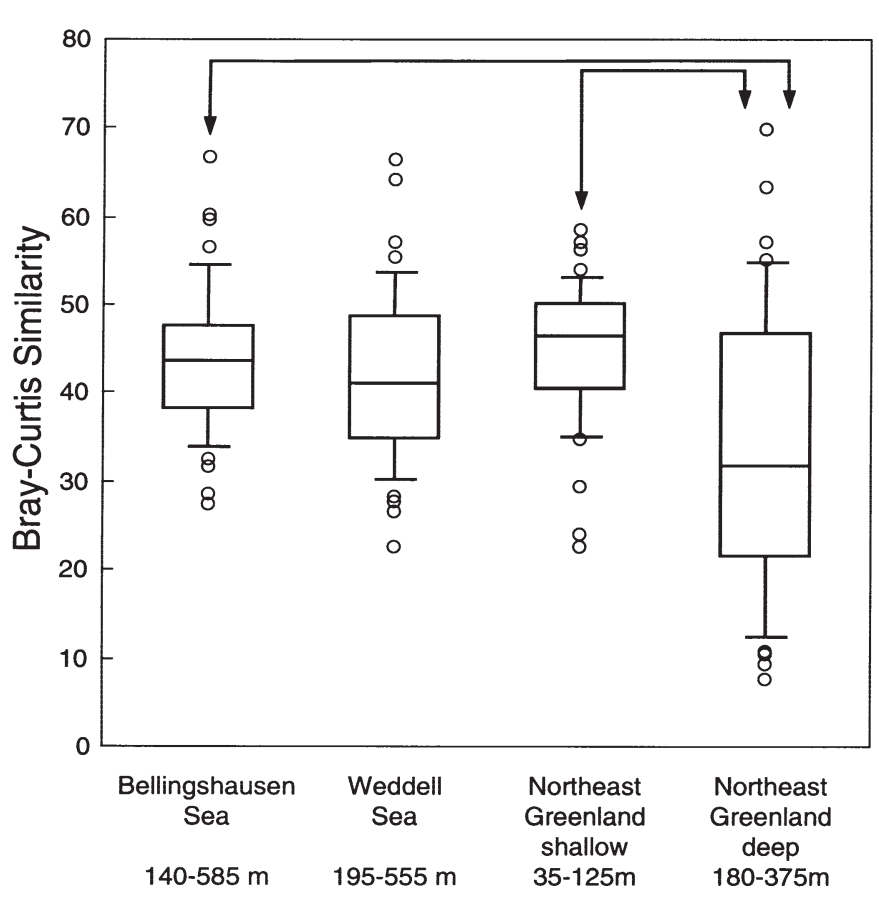

Fig. 3. Between-habitat diversity ( $\beta$ ). Distribution of similarity coefficients between all possible combinations of stations (Further details as in Fig. 2 legend). Sample size (n) $=45$ for each study site
Graphs of the rarefaction richness estimator, $E\left(S_{70}\right)$, and the number of taxa for different numbers of pooled samples are shown in Fig. 4. The lines cannot be compared statistically because the values are not independent. The Weddell Sea stations started with the highest mean for $E\left(S_{70}\right)$ for single stations (high $\alpha$-diversity). After a steep increase between the values for 1 and 2
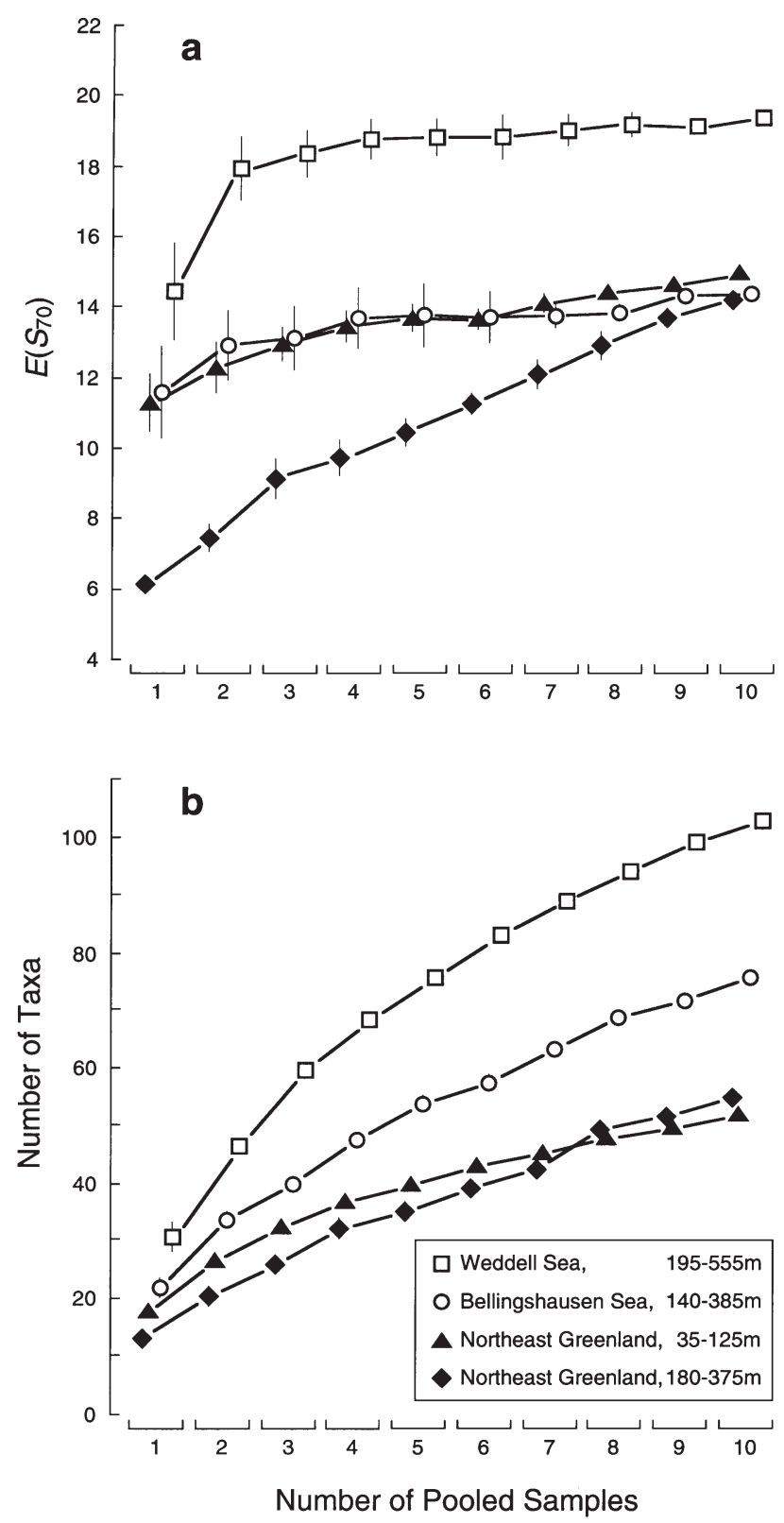

Fig. 4. Between-habitat diversity. (a) Rarefaction richness estimator $E\left(S_{70}\right)$, (b) number of taxa. Cumulative values plotted against number of pooled samples for 10 random permutations of stations in Weddell and Bellingshausen Sea and off northeast Greenland. Symbols are mean values $(n=10)$, except for the values for 10 pooled samples. Bars show $\pm \mathrm{SE}$; where no bars are shown, the SE is smaller than the size of the symbol 
pooled stations, the $E\left(S_{70}\right)$ value remained at a level between 18.0 and 19.4. The graphs for the Bellingshausen Sea and the deeper stations off northeast Greenland showed only a slight increase with increasing number of pooled samples, while the graph for the shallow Arctic stations exhibited a different shape altogether. Starting with the lowest mean diversity for the single stations (low $\alpha$-diversity), the entire curve increased sharply, indicating high $\beta$-diversity, ending with an estimator of 14.2 for all 10 stations. This value is comparable with those of 14.3 and 14.9 for the Bellingshausen Sea and the deeper Arctic stations, respectively.

The total number of taxa found in each investigation area amounted to 103 in the Weddell Sea and 76 in the Bellingshausen Sea. Off northeast Greenland the values were lower, with totals of 55 and 52 taxa recorded for the shallow and deeper stations, respectively. In addition, the graphs showing the cumulative number of taxa against the number of pooled samples (Fig. 4b) indicate that the species turnover between stations was less apparent in the Arctic than in the Antarctic.

\section{DISCUSSION}

\section{Methods}

Compared with trawls, which have long been the main means of investigating large bottom fauna, video material provides quantitative and therefore comparable data on the epibenthic megafauna (Holme \& McIntyre 1984, Hamada et al. 1986). However, sometimes organisms can be indistinguishable from other structures, particularly where bryozoans, sponges and corals almost completely cover the sea floor. Furthermore, density estimates are influenced by the optical resolution and, thus, there are limits to species identification. We tried to minimise any potential bias caused by these problems by keeping the distance between the ROV and the sea bed relatively small and by enlisting the support of experts to help with identification. We did not focus on absolute diversity values (if this is possible in fact at all), but on their relative differences.

\section{Within-habitat $(\alpha)$ diversity}

Within-habitat diversity reflects coexistence among organisms that are interacting with each other by competing for the same resources, or otherwise using the same environment (Huston 1994). The number of species and the evenness of their relative abundance are the 2 statistical properties used to quantify species diversity. Besides recording the number of taxa alone, we calculated values for species diversity by the method of Hurlbert (1971), which combines both components. Values for diversity in this narrower sense of the term, i.e. the number of taxa in combination with the distribution of individuals over the taxa, showed that the diversity at each station can be much higher in the Antarctic, particularly in the Weddell Sea, than in the Arctic (Fig. 2a). However, when stations from a similar depth range were compared, this difference was not significant.

Piepenburg et al. (1997) found results very similar to ours based on asterozoans. They obtained the highest values (with a narrow interquartile range) for a cluster of stations in the eastern Weddell Sea. However, the other station groups at a comparable depth to ours (the cluster TRANS off Northeast Greenland and SOUTH in the Weddell Sea) did not differ at all from each other. The broad range in diversity which we found in the Weddell Sea can be explained by the similarity of our stations to both the cluster EAST and SOUTH of Piepenburg et al. (1997). Apparently, megabenthic assemblages of oligomixity (George 1977), whereby a single species dominates in density, are not restricted to the Arctic. Even assemblages with many species can be dominated by a single sponge or bryozoan, which reduces an otherwise high evenness (Arntz et al. 1997). On the other hand, assemblages with only a few taxa can exhibit high diversity because of a high evenness (Gutt et al. 1999).

This method has shown that there are more taxa present in megabenthic communities in the Antarctic than in the Arctic (Fig. 4b). This finding confirms the conclusion of various large-scale comparisons between Antarctic and Arctic benthos based on single taxonomic groups. Depending on the taxa considered, Antarctic benthic communities have between 50 and $>100 \%$ more species (Knox \& Lowry 1977, White 1984, Grebmeier \& Barry 1991, Brey et al. 1994, Dayton et al. 1994). Results obtained by Piepenburg et al. (1997) from almost the same investigation areas (Weddell Sea, off northeast Greenland) as ours showed between 175 and $250 \%$ more asterozoan species in the Antarctic than in the Arctic. Many of the Antarctic taxa have a high percentage of endemic species, which make up between 57 and $95 \%$ of the total (Dayton 1990). In contrast, endemism is low in the high Arctic because of the the dominance of boreo-arctic species (George 1977). This striking difference is commonly attributed to the fact that the Antarctic system is much older and has been isolated for a longer period of time (Hempel 1985). These characteristics, together with the relatively stable Antarctic environment (Dayton et al. 1994), are presumed to be the main reasons for the development of a unique fauna, rich in species and well adapted to a cold-water system (Clarke 1990). 
Besides these general differences between the 2 polar systems, recent biological structures and processes can influence species richness on a regional scale. Gutt \& Starmans (1998) found a significant correlation between the abundance of large sponges and the number of all other megabenthic species present in the suspension-feeder-dominated assemblages on the eastern Weddell Sea shelf. Here sponges are a prominent benthic group (Voß 1988, Barthel \& Gutt 1992, Gutt \& Koltun 1995, Gutt \& Starmans 1998, Starmans et al. 1999) and provide habitats for numerous epizoic animals (Gutt \& Schickan 1998) serving as hosts for commensals (Kunzmann 1996), thus creating a high species richness. Indeed, we found the highest numbers of taxa in these 'multi-storied assemblages' in the Weddell Sea. In contrast, assemblages lacking this 3-dimensional structure, such as a few stations in the Weddell Sea and most stations in the Bellingshausen Sea, as well as the Arctic stations, were generally less diverse. Nevertheless, our data do not show that high species richness is a general characteristic of Antarctic megabenthic assemblages. In particular, Antarctic deposit-feeder assemblages at stations with a predominantly soft-bottom have low numbers of taxa which fall into the range typical of the Arctic stations (Gutt \& Starmans 1998, Starmans et al. 1999).

\section{Between-habitat $(\beta)$ diversity}

The concept of between-habitat diversity was first introduced by Whittaker (1960). Essentially, it is a measure of how different or similar samples are in terms of their species composition (Magurran 1988). In contrast to most of the methods for measuring $\beta$-diversity (summarized in Wilson \& Shmida 1984) which use only presence and absence data, the use of a quantitative index (such as the Bray-Curtis similarity [Bray \& Curtis $1957]$ and the $E\left[S_{70}\right]$ values for pooled samples) has the advantage that the different species and their abundances are taken into account.

The similarities between pairs of stations varied most off Greenland, at <140 m depth, where the median was the lowest and therefore the $\beta$-diversity highest overall. The range of similarities was smaller, but still well pronounced for the other investigation areas, although the medians were slightly higher, still indicating a high $\beta$-diversity. On a regional scale, a high $\beta$-diversity is therefore a characteristic of both Antarctic and Arctic megabenthic communities in deeper shelf areas. A high degree of local patchiness of benthic invertebrates is likely to be responsible for the observed high $\beta$-diversity. Patchy distribution on a regional and local scale has already been described for both Arctic (Mayer \&
Piepenburg 1996, Piepenburg \& Schmid 1996) and Antarctic (Gutt 1991, Gutt \& Piepenburg 1991, Gutt \& Koltun 1995) shelf communities. This patchiness seems to be mainly effected by variation in sediment type and benthic food supply, which depends on primary production and sedimentation, which again depend on current regimes, hydrographic factors and sea-ice cover (Grebmeier \& Barry 1991). Other, so far unknown but relevant factors are generally referred to as 'historical' influences.

A more detailed insight into how $\beta$-diversity is generated is provided by the graphs in Fig. 4. Interestingly, the curve of the rarefaction richness estimator $E\left(S_{70}\right)$ for the Weddell Sea stations showed an initially sharp rise between the mean of single stations ( $\alpha$-diversity) and of the sum of 2 stations, and then stabilised at a high level of diversity (Fig. 4a). The occurrence of both suspension-feeder and deposit-feeder assemblages (see above) with their different taxa compositions is likely to be responsible for this pattern. The inclusion of both a suspension-feeder and a depositfeeder assemblage in the first step of the summation apparently led to the initial increase in diversity and, furthermore, to a high overall diversity, partly due to the large overall number of taxa (Fig. 4b). Thus, the environmental heterogeneity of the Weddell Sea shelf described above leads to a high between-habitat diversity. Despite a comparably high $\beta$-diversity (Fig. 3), the stations of the Bellingshausen Sea and the deeper shelf off northeast Greenland do not show a substantial increase in diversity and have distinctly lower values for overall diversity (Fig. 4a). Compared with the deeper stations off northeast Greenland, however, those in the Bellingshausen Sea show a steeper increase and higher overall number of taxa (Fig. 4b). A similarly high $\beta$-diversity, despite a higher species turnover between stations and greater overall number of taxa in the Bellingshausen Sea, could be due to the same dominant taxa occurring at different stations at the same time as the other taxa present varied. On a larger scale, the more homogenous environmental settings in this area presumably lead to these minor differences in the dominant species. The occurrence of rare taxa, however, probably depends on smallscale factors, such as the abundance of large stones which provide a suitable substrate for various sessile animals requiring solid anchorage.

The shallow stations ( $<140 \mathrm{~m}$ ) off northeast Greenland exhibit an interesting diversity pattern that is markedly different from that of the deeper stations. There is a noticeably low $\alpha$-diversity (Figs $2 \& 4 a$ ), high $\beta$-diversity (Fig. 3) and a substantial increase in both diversity and the number of taxa throughout cumulative summation (Fig. 4). These phenomena can be caused by pronounced small or meso-scale patchiness 
in the distribution of different assemblages, most of which are dominated by different taxa, such as the sea urchins Stronglyocentrotus spp., the isopod Arcturus cf. hastiger, the brittle stars Ophiacantha bidenta and Ophiocten sericeum and the soft coral Gersemia spp.

However, not every station is strongly dominated by different taxa. In fact, even the highest overall similarities were calculated for this area (Fig. 3), resulting in the broad range of similarities. Piepenburg \& Schmid (1996) also found the lowest degree of evenness and, hence, the highest species dominance on shallow shelf banks $(<150 \mathrm{~m})$ off northeast Greenland. They reported elevated numbers of Ophiocten sericeum, Ophiura robusta, Ophiacantha bidenta, Stronglyocentrotus pallidus and Arcturus cf. hastiger. Similar dominance patterns have been reported from shallow water in the Antarctic (Arntz et al. 1994 and references therein; Cattaneo-Vietti et al. 1997, Gambi et al. 1997, Sahade et al. 1998). We believe that high dominance and thereby low $\alpha$-diversity and high $\beta$-diversity are related to environmental stress, and partly, therefore, by the way in which this affects environmental heterogeneity. Feder et al. (1994) came to similar conclusions. They also related offshore/inshore dissimilarities in diversity in the northeastern Chukchi Sea to regional differences in environmental stress. Shallow waters off northeast Greenland are exposed to a potentially greater degree of bottom disturbance by ice-gouging (Barnes et al. 1984, Woodworth-Lynas et al. 1991, Gutt et al. 1996, Conlan et al. 1998), intense wave action (authors' unpubl. obs.) and the feeding activities of walrus (Oliver et al. 1985). The more stable conditions at greater depths lead to a comparatively high $\alpha$-diversity and more moderate $\beta$-diversity.

Summarising, our comparative studies indicate that, although Antarctic waters house more taxa than the waters off northeast Greenland, the generally assumed higher diversity of Antarctic assemblages is an overgeneralisation. Furthermore, our findings provide evidence that both spatial heterogeneity and environmental stress lead to high between-habitat diversity.

Acknowledgements. The following experts assisted in the identification of different species/taxa: V. M. Koltun (sponges), S. Grebelny (anthozoans), N. V. Slepkova (octocorallians), H. Ristedt (bryozoans), S. Hain (molluscs), M. Stiller (polychaetes), F. Krapp (pycnogonoids), C. Dahm, D. Piepenburg and I. Smirnov (ophiuroids), C. Monniot (ascidians). We would like to thank all these colleagues. In addition, we thank W. Dimmler (ROV service) for technical assistance, as well as colleagues who supported an earlier version of the manuscript based on a presentation at the Linnean Society, London, and 3 anonymous referees. This is publication No. 1502 of the Alfred Wegener Institute, supported by Deutsche Forschungsgemeinschaft (DFG) grant Gu 390/1-2.

\section{LITERATURE CITED}

Arntz WE, Brey T, Gallardo VA (1994) Antarctic zoobenthos. Oceanogr Mar Biol Annu Rev 32:241-304

Arntz WE, Gutt J, Klages M (1997) Antarctic marine biodiversity: an overview. In: Battaglia B, Valencia J, Walton DWH (eds) Antarctic communities: species, structure and survival. Cambridge University Press, Cambridge, p 3-14

Barnes PW, Rearic DM, Reimnitz E (1984) Ice gouging characteristics and processes. In: Barnes PW, Schell D, Reimnitz E (eds) The Alaskan Beaufort Sea: ecosystems and environments. Academic Press, San Diego, p 185-212

Barthel D, Gutt J (1992) Sponge associations in the eastern Weddell Sea. Antarct Sci 4:137-150

Bray JR, Curtis JT (1957) An ordination of the upland forest of Southern Wisconsin. Ecol Monogr 27:225-349

Brey T, Klages M, Dahm C, Gorny M, Gutt J, Hain S, Stiller M, Arntz WE, Wägele JW, Zimmermann A (1994) Antarctic benthic diversity. Nature 368:297

Cattaneo-Vietti R, Chiantore M, Albertelli G (1997) The population structure and ecology of the Antarctic scallop Adamussium colbeki (Smith 1902) at Terra Nova Bay (Ross Sea, Antarctica). Sci Mar 61 (Suppl 2):15-24

Clarke A (1990) Temperature and evolution: Southern Ocean cooling and the Antarctic marine fauna. In: Kerry KR, Hempel G (eds) Antarctic ecosystems. Ecological change and conservation. Springer-Verlag, Berlin, p 9-22

Clarke KR, Warwick RM (1994) Change in marine communities: an approach to statistical analysis and interpretation. Natural Environment Research Council, Plymouth

Conlan KE, Lenihan HS, Kvitek RG, Oliver JS (1998) Ice scour disturbance to benthic communities in the Canadian High Arctic. Mar Ecol Prog Ser 166:1-16

Dayton PK (1990) Polar benthos. In: Smith WO (ed) Polar oceanography, part B: chemistry, biology, and geology. Academic Press, Boston, MA, p 631-685

Dayton PK, Mordida BJ, Bacon F (1994) Polar marine communities. Am Zool 34:90-99

Dunbar MJ (1968) Ecological development in polar regions: a study in evolution. Prentice-Hall, Englewood Cliffs, NJ

Dunbar MJ (1977) The evolution of polar ecosystems. In: Llano GA (ed) Adaptation within the Antarctic ecosystems. Smithsonian Institute, Washington, DC, p 1063-1076

Feder HM, Naidu AS, Jewett SC, Hameedi JM, Johnson WR, Whitledge TE (1994) The northeastern Chukchi Sea: benthos-environmental interactions. Mar Ecol Prog Ser 111: 171-190

Fütterer DK (ed) (1988) The expedition ANTARKTIS-VI of RV 'Polarstern' in 1987/1988. Ber Polarforsch 58:1-267

Galéron J, Herman RL, Arnaud PM, Arntz WE, Hain S, Klages $M$ (1992) Macrofaunal communities on the continental shelf and slope of the southeastern Weddell Sea, Antarctica. Polar Biol 12:283-290

Gambi MC, Castelli A, Guizzardi M (1997) Polychaete populations of the shallow soft bottoms off Terra Nova Bay (Ross Sea, Antarctica): distribution, diversity and biomass. Polar Biol 17:199-210

George RY (1977) Dissimilar and similar trends in Antarctic and Arctic marine benthos. In: Dunbar MJ (ed) Polar oceans. Arctic Institute of North America, Calgary, p 391-408

Grebmeier JM, Barry JP (1991) The influence of oceanographic processes on pelagic-benthic coupling in polar regions: a benthic perspective. J Mar Syst 2:495-518

Gutt J (1991) On the distribution and ecology of holothurians in the Weddell Sea (Antarctica). Polar Biol 11:145-155

Gutt J, Koltun VM (1995) Sponges of the Lazarev and Wed- 
dell Sea, Antarctica: explanations for their patchy occurrence. Antarct Sci 7:227-234

Gutt J, Piepenburg D (1991) Dense aggregations of three deep-sea holothurians in the southern Weddell Sea, Antarctica. Mar Ecol Prog Ser 68:277-285

Gutt J, Schikan T (1998) Epibiotic relationships in the Antarctic benthos. Antarct Sci 10:398-405

Gutt J, Starmans A (1998) Megabenthic structure and biodiversity in the Weddell and Lazarev Sea (Antarctic): ecological role of physical parameters and biological interactions. Polar Biol 20:229-247

Gutt J, Starmans A, Dieckmann G (1996) Impact of iceberg scouring on polar benthic habitats. Mar Ecol Prog Ser 137: 311-316

Gutt J, Helsen E, Arntz WE, Buschmann A (1999) Biodiversity and community structure of the mega-epibenthos in the Magellan area (South America). Sci Mar 63 (Suppl 1): $155-170$

Hamada E, Numanami H, Naito Y, Taniguchi A (1986) Observation of the marine benthic organisms at Syowa Station in Antarctica using a remotely operated vehicle. Mem Natl Inst Polar Res (Tokyo) Spec Issue 40:289-298

Hedgpeth JW (1971) Perspectives of benthic ecology in Antarctica. In: Quam LO (ed) Research in the Antarctic. American Association for the Advancement of Science, Washington, DC, p 93-136

Hempel G (1985) On the biology of polar seas, particularly the Southern Ocean. In: Gray JS, Christiansen ME (eds) Marine biology of polar regions and effects of stress on marine organisms. Wiley, Chichester, p 3-34

Hirche HJ, Kattner G (1994) The 1993 Northeast Water Expedition: scientific cruise report of RV 'Polarstern' Antarctic cruises ARK/2 and 3, USCG 'Polar Sea' cruise NEWP and the NEWLand expedition. Ber Polarforsch 142:1-190

Holme NA, McIntyre AD (eds) (1984) Methods for the study of marine benthos. Blackwell Scientific Publications, Oxford

Hurlbert HS (1971) The nonconcept of species diversity: a critique and alternative parameters. Ecology 52:577-586

Huston MA (1994) Biological diversity. Cambridge University Press, Cambridge

Knox GA, Lowry JK (1977) A comparison between the benthos of the Southern Ocean and the North Polar Ocean with special reference to the Amphipoda and the Polychaeta. In: Dunbar MJ (ed) Polar oceans. Arctic Institute of North America, Calgary, p 423-462

Kunzmann K (1996) Die mit ausgewählten Schwämmen (Hexactinellida und Demospongiae) aus dem Weddellmeer, Antarktis, vergesellschaftete Fauna. Ber Polarforsch 210:1-93

Lukin V, Provorkin A (1992) Ice observations in the eastern Weddell and Lazarev Seas, January-March 1991. In:

Editorial responsibility: Otto Kinne (Editor),

Oldendorf/Luhe, Germany
Bathmann U, Schulz-Baldes M, Fahrbach E, Smetacek V, Hubberten HW (eds) The Expedition Antarktis IX/1-4 of the Research Vessel 'Polarstern' in 1990/91. Ber Polarforsch 100:107-124

Magurran AE (1988) Ecological diversity and its measurement. Croom Helm, London

Mayer M, Piepenburg D (1996) Epibenthic community patterns on the continental slope off East Greenland at $75^{\circ} \mathrm{N}$. Mar Ecol Prog Ser 143:151-164

Miller H, Grobe H (1996) The Expedition ANTARKTIS-XI/3 of RV 'Polarstern' in1994. Ber Polarforsch 188:1-115

Oliver JS, Kvitek RG, Slattery PN (1985) Walrus feeding disturbance: scavenging habits and recolonisation of the Bering Sea benthos. J Exp Mar Biol Ecol 91:233-246

Piepenburg D, Schmid MK (1996) Distribution, abundance, biomass, and mineralization potential of the epibenthic megafauna of the Northeast Greenland shelf. Mar Biol 125:321-332

Piepenburg D, Voß J, Gutt J (1997) Assemblages of sea stars (Echinodermata: Asteroidea) and brittle stars (Echinodermata: Ophiuroidea) in the Weddell Sea (Antarctica) and off Northeast Greenland (Arctic): a comparison of diversity and abundance. Polar Biol 17:305-322

Sachs L (1984) Angewandte Statistik: Anwendungen statistischer Methoden. Springer-Verlag, Berlin

Sahade R, Tatián M, Kowalke J, Kühne S, Esnal GB (1998) Benthic faunal associations on soft substrates at Potter Cove, King George Island, Antarctica. Polar Biol 19:85-91

Sanders HL (1968) Marine benthic diversity: a comparative study. Am Nat 102:243-282

Schneider W, Budéus G (1994) The Northeast Water polynya (Greenland Sea); Part I. A physical concept of its generation. Polar Biol 14:1-9

Starmans A, Gutt J, Arntz WE (1999) Mega-epibenthic communities in Arctic and Antarctic shelf areas. Mar Biol 135: $269-280$

Voß J (1988) Zoogeographie und Gemeinschaftsanalyse des Makrozoobenthos des Weddellmeeres (Antarktis). Ber Polarforsch 45:1-145

White MG (1984) Marine benthos. In: Laws RM (ed) Antarctic ecology. Academic Press, London, p 421-461

Whittaker RH (1960) Vegetation of the Siskiyou Mountains, Oregon and California. Ecol Monogr 30:279-338

Wilson MV, Shmida A (1984) Measuring beta diversity with presence-absence data. J Ecol 72:1055-1064

Woodworth-Lynas CMT, Josenhans HW, Barrie JV, Lewis CFM, Parrott DR (1991) The physical processes of seabed disturbance during iceberg grounding and scouring. Cont Shelf Res 11:939-961

Yevsyeyev VV (1990) The major features of ice conditions in the Bellingshausen Sea. Geod Geophys Veröff Ber 1:325-330

Submitted: January 16, 2001; Accepted: June 5, 2001

Proofs received from author(s): January 1, 2002 